\title{
Combining Ability Analysis in Ridge Gourd [Luffa acutangula (L.) Roxb.]
}

\author{
D. Nandhini*, M. Ananthan, V. Krishnamoorthy and G. Anand \\ Department of Horticulture, AC\&RI, TNAU, Madurai-625 104, India \\ Department of Vegetable Crops, HC\&RI, TNAU, Coimbatore-641 003, India \\ *Corresponding author
}

\begin{tabular}{|c|c|}
\hline & A B S T R A C T \\
\hline $\begin{array}{l}\text { K e y w or d s } \\
\text { Combining ability, Luffa } \\
\text { acutangula, Ridge gourd }\end{array}$ & \multirow{3}{*}{$\begin{array}{l}\text { The present study was carried out at Department of Horticulture, Agricultural College and } \\
\text { Research Institute, Madurai during } 2015-2016 \text { to study the Combining ability estimates for } \\
\text { growth, earliness, yield and quality parameters. Sixteen crosses obtained on Line } \times \text { Tester } \\
\text { approach were evaluated for fifteen traits. The variance due to } s c a \text { was higher than the gca } \\
\text { for all the characters, indicating the importance of non-additive gene action. Maximum and } \\
\text { positively significant } s c a \text { effects was observed in the cross } \mathrm{L}_{3} \times \mathrm{T}_{1}(0.36) \text { followed by } \mathrm{L}_{1} \times \\
\mathrm{T}_{4}(0.33) \text { for fruit yield per vine as well as fruit yield per hectare. } \mathrm{L}_{4} \times \mathrm{T}_{4} \text { showed } \\
\text { significant } s c a \text { effects for earliness characters like days to first female flower appearance (- } \\
2.75) \text { and days to first harvest (-8.74). }\end{array}$} \\
\hline Article Info & \\
\hline $\begin{array}{l}\text { Accepted: } \\
\text { 22 April } 2018 \\
\text { Available Online: } \\
10 \text { May } 2018\end{array}$ & \\
\hline
\end{tabular}

\section{Introduction}

Ridge gourd is popularly known as kalitori and also called as angled gourd, angled loofah, Chinese okra, silky gourd and ribbed gourd. Ridge gourd [Luffa acutangula (L).Roxb] or Ribbed gourd is an underexploited vegetable crop and it is an important Cucurbitaceous vegetable crop. It is grown as mixed crop in the river bed areas and as monocrop in the garden lands. It is widely grown in tropical and subtropical parts of the world. Ridge gourd belongs to genus Luffa of Cucurbitaceae and has a chromosome no. $2 n=2 x=26$. The genus derives its name from product "Loofah" which is used in bathing sponge, doormats, pillows and cleaning utensils. Ridge gourd, being predominantly monoecious, is a cross pollinated crop and provides ample scope for utilization of the hybrid vigour. During recent years, the exploitation of hybrid vigour and selection of parents on the basis of combining ability have expanded a new alley in crop improvement. These studies are generally used to assess the performance of lines in hybridization programme and to understand the gene action involved in different characters.

\section{Materials and Methods}

An experiment was carried out at Department of Horticulture, Agricultural College and Research Institute, Madurai during rabi 2015. The experimental material consists of eight parents viz. PKM-1 $\left(\mathrm{L}_{1}\right), \mathrm{CO}-1\left(\mathrm{~L}_{2}\right)$, LA 12 $\left(\mathrm{L}_{3}\right)$, LA $19\left(\mathrm{~L}_{4}\right)$ used as lines and four testers namely LA $7\left(\mathrm{~T}_{1}\right)$, LA $16\left(\mathrm{~T}_{2}\right)$, LA17 $\left(\mathrm{T}_{3}\right)$ and 
LA $20\left(\mathrm{~T}_{4}\right)$ and one standard check CO-1. The experiment consists of eight parents and 16 hybrids and was evaluated in randomized block design with three replications. A inter row spacing of $2 \mathrm{~m}$ and intra row spacing of 2 $\mathrm{m}$ was followed and other cultural practices were followed as per the production guidelines of Tamilnadu Agricultural University. Observations on five randomly selected plants were recorded for various growth, earliness, yield and quality parameters. The Line $x$ Tester analysis is one of the most appropriate methods in preliminary screening of the breeding material for combining ability and data was analyzed as per the Kempthorne to determine general and specific combining ability.

\section{Results and Discussion}

The analysis of variance (Table 1) for genotypes showed significant differences for all the characters. The estimates of mean sum of squares due to parents showed significant differences for all the characters except node to first female flower, per cent fruit set, number of fruits per vine and fruit yield per vine indicating the presence of sufficient variability among the parents studied. The magnitude of variance due to $s c a$ was greater than $g c a$ for all the characters and gca: sca less than unity also confirmed the preponderance of non-additive gene action for all the traits. This result is expected as ridge gourd as cross pollinated crop thus exhibiting predominance of dominance genetic variance in comparison to additive component. These results are close conformity with Purohit (2007) and Neeraja (2008).

The estimates of $g c a$ effects of each parents are presented in Table 2. Among the four testers, $\mathrm{T}_{2}(0.69)$ showed highly significant and positive $g c a$ effects for fruit yield per vine, the highest was observed in the line $\mathrm{L}_{3}$ (0.52). The parent $\mathrm{L}_{3}$ was found to be good general combiner for number of fruits per vine and estimated fruit yield per hectare these results are in agreement with Shahe and Kale (2003).

The line $\mathrm{L}_{3}(-1.56)$ and tester $\mathrm{T}_{1}(-1.25)$ exhibited negative and significant $g c a$ effects for days to first female flower appearance. Highest significant gca effects for days to first harvest was observed in the parent $\mathrm{L}_{3}(-9.54)$ and $\mathrm{T}_{2}$ (-4.51). The parents viz., $\mathrm{L}_{3}$ and $\mathrm{T}_{2}$ exhibited the significant and negative $g c a$ effects for both days to first female flower appearance and days to first harvest so, these parents may be used in breeding programme for earliness. These results are in agreement with Ahmed et al., 2006.

The female parent $\mathrm{L}_{3}$ (1.64) and tester $\mathrm{T}_{2}$ (1.61) and $\mathrm{T}_{3}$ (1.23) had positive significant gca effects for number of leaves at 90 DAS and the line $\mathrm{L}_{1}(0.30)$ and tester $\mathrm{T}_{2}(0.34)$ showed positive significant gca effects for number of branches at 90 DAS. The average fruit weight in the line $\mathrm{L}_{2}(0.73)$ exhibited maximum and significant $g c a$ effects whereas, $\mathrm{L}_{2}$ (2.58) exhibited significant and maximum gca effects for fruit length. The line $\mathrm{L}_{3}$ was the good general combiner for number of fruits per vine (0.52), fruit length $(0.91)$, fruit yield per vine (0.10), estimated fruit yield per hectare $(0.72)$ whereas, $\mathrm{L}_{2}(0.15)$ exhibited the positive and significant $g c a$ effects for flesh thickness and $\mathrm{L}_{3}$ (0.36) showed positive significant gca effects for rind thickness. Positive and significant $g c a$ effect was observed in the tester $T_{3}(0.03)$ for total crude fibre content. This indicating that there was strong tendency of transmission of higher gain from the parents to the off springs. The present findings corroborated the earlier work of Rao et al., (2000).

However parents $\mathrm{L}_{1}, \mathrm{~L}_{2}, \mathrm{~L}_{3}$ and $\mathrm{T}_{1}, \mathrm{~T}_{2}$ exhibited significant $g c a$ effects for the most of the traits. 
Table.1 Analysis of variance for combining ability of ridge gourd (Luffa acutangula L.)

\begin{tabular}{|c|c|c|c|c|c|c|c|c|}
\hline $\begin{array}{l}\text { SI. } \\
\text { No. }\end{array}$ & Character & Replications & Genotypes & Crosses & Lines & Testers & $\begin{array}{l}\text { Line } \quad x \\
\text { Tester }\end{array}$ & Error \\
\hline & Degree of freedom & 2 & 23 & 15 & 3 & 3 & 9 & 30 \\
\hline 1 & Number of leaves on 90 DAS & 17.01 & $46.79 *$ & $25.49 *$ & $30.26^{*}$ & $37.92 *$ & $19.76^{*}$ & 3.22 \\
\hline 2 & $\begin{array}{l}\text { Number of branches at } 90 \\
\text { DAS }\end{array}$ & 0.01 & $0.63 *$ & $0.59 *$ & $1.13 *$ & $0.73 *$ & $0.35^{*}$ & 0.06 \\
\hline 4 & Node to first female flower & 2.45 & $2.42 *$ & $2.33^{*}$ & 2.42 & 1.69 & $2.52 *$ & 0.84 \\
\hline 5 & Days to first harvest & 143.27 & $266.88 *$ & $264.42 *$ & $540.30 *$ & $135.76^{*}$ & $215.35^{*}$ & 15.82 \\
\hline 6 & Sex ratio & 0.04 & $2.20 *$ & $2.65^{*}$ & $2.17 *$ & $3.34 *$ & $2.58 *$ & 0.15 \\
\hline 7 & Number of fruits per vine & 0.69 & $5.35^{*}$ & $3.70^{*}$ & 1.62 & 2.84 & $4.68 *$ & 1.29 \\
\hline 10 & Fruit diameter & 0.58 & $5.01 *$ & $2.61 *$ & 1.17 & $4.03 *$ & $2.61 *$ & 0.58 \\
\hline 11 & Fruit yield per vine & 0.02 & $0.25^{*}$ & $0.19 *$ & $0.20 *$ & 0.00 & $0.25 *$ & 0.05 \\
\hline 12 & $\begin{array}{l}\text { Estimated fruit yield per } \\
\text { hectare }\end{array}$ & 3.58 & $14.28 *$ & $10.76^{*}$ & $10.93 *$ & 0.19 & $14.22 *$ & 1.25 \\
\hline 13 & Rind thickness & 0.01 & $0.71^{*}$ & $0.45^{*}$ & $1.77 *$ & 0.01 & $0.16^{*}$ & 0.02 \\
\hline 14 & Flesh thickness & 0.01 & $0.14 *$ & $0.11 *$ & $0.19 *$ & 0.01 & $0.12 *$ & 0.05 \\
\hline 15 & Total crude fibre content & 0.01 & $0.01 *$ & $0.01 *$ & 0.01 & $0.01 *$ & 0.01 & 0.01 \\
\hline
\end{tabular}

* Significant at $5 \%$ level 
Table. 2 General combining ability effects of parents for growth, earliness, yield and quality parameters in ridge gourd

\begin{tabular}{|c|c|c|c|c|c|c|c|c|c|c|c|c|c|c|c|c|}
\hline $\begin{array}{l}\text { SI. } \\
\text { NO. }\end{array}$ & Parent & $\begin{array}{l}\text { Number } \\
\text { of leaves } \\
\text { on } \quad 90 \\
\text { DAS }\end{array}$ & $\begin{array}{l}\text { Number } \\
\text { of } \\
\text { branches } \\
\text { at } 90 \text { DAS }\end{array}$ & $\begin{array}{l}\text { Days to } \\
\text { first } \\
\text { female } \\
\text { flower }\end{array}$ & $\begin{array}{l}\text { Node to } \\
\text { first } \\
\text { female } \\
\text { flower }\end{array}$ & $\begin{array}{l}\text { Days to } \\
\text { first } \\
\text { harvest }\end{array}$ & Sex ratio & $\begin{array}{l}\text { Number } \\
\text { of fruits } \\
\text { per vine }\end{array}$ & $\begin{array}{l}\text { Average } \\
\text { fruit } \\
\text { weight }\end{array}$ & $\begin{array}{l}\text { Fruit } \\
\text { length }\end{array}$ & $\begin{array}{l}\text { Fruit } \\
\text { diameter }\end{array}$ & $\begin{array}{l}\text { Fruit } \\
\text { yield per } \\
\text { vine }\end{array}$ & $\begin{array}{l}\text { Estimated } \\
\text { fruit yield } \\
\text { per hectare }\end{array}$ & $\begin{array}{l}\text { Rind } \\
\text { thick } \\
\text { ness }\end{array}$ & $\begin{array}{l}\text { Flesh } \\
\text { thick } \\
\text { ness }\end{array}$ & $\begin{array}{l}\text { Total } \\
\text { crude fibre } \\
\text { content }\end{array}$ \\
\hline 1. & $\mathbf{L}_{1}$ & 0.14 & $0.30 * *$ & $1.74 * *$ & -0.38 & 1.26 & -0.20 & -0.04 & $-10.97 * *$ & $-1.10 *$ & -0.06 & $-0.19 *$ & $-1.38 * *$ & $-0.29 * *$ & $-0.14 *$ & -0.00 \\
\hline 2. & $\mathbf{L}_{2}$ & $-2.17 * *$ & $-0.35 * *$ & -0.01 & 0.51 & $6.16 * *$ & $-0.43 * *$ & -0.34 & $10.73 * *$ & $2.58 * *$ & 0.17 & 0.07 & 0.56 & $-0.37 * *$ & $0.15 *$ & 0.02 \\
\hline 3. & $\mathbf{L}_{3}$ & $1.64 * *$ & $0.21 * *$ & $-1.56^{* * *}$ & 0.24 & $-9.54 * *$ & 0.07 & 0.52 & -3.28 & 0.91 & -0.41 & $0.10 *$ & $0.72 *$ & $0.36 * *$ & -0.07 & -0.01 \\
\hline 4. & $\mathbf{L}_{4}$ & 0.38 & $-0.16 *$ & -0.17 & -0.38 & 2.12 & $0.56 * *$ & -0.14 & 3.52 & $-2.40^{* *}$ & 0.30 & 0.01 & 0.11 & $0.31 * *$ & 0.05 & -0.01 \\
\hline 5. & $\mathbf{T}_{1}$ & $-2.24 * *$ & -0.08 & $-1.25 *$ & 0.50 & 2.13 & $-0.75^{* * *}$ & -0.11 & -2.85 & $0.95 *$ & $0.71 * *$ & -0.02 & -0.11 & 0.05 & -0.02 & $-0.04 * *$ \\
\hline 6. & $\mathbf{T}_{2}$ & $1.61 * *$ & $0.34 * *$ & -1.06 & -0.31 & $-4.51 * *$ & $0.46 * *$ & $0.69 *$ & -2.69 & $-1.66 * *$ & -0.15 & 0.03 & 0.16 & -0.00 & -0.01 & 0.00 \\
\hline 7. & $\mathbf{T}_{3}$ & $1.23 *$ & -0.01 & 0.06 & -0.27 & -0.58 & 0.03 & -0.46 & 4.75 & $0.96 *$ & 0.12 & 0.01 & 0.05 & -0.04 & -0.02 & 0.01 \\
\hline \multirow[t]{2}{*}{8.} & $\mathbf{T}_{4}$ & -0.61 & $-0.25 * *$ & $2.25 * *$ & 0.08 & $2.96 *$ & $0.25 *$ & -0.12 & 0.78 & -0.25 & $-0.68 * *$ & -0.02 & -0.10 & -0.00 & 0.05 & $0.03 * *$ \\
\hline & SEd & 0.73 & 0.10 & 0.76 & 0.37 & 1.62 & 0.16 & 0.46 & 3.85 & 0.64 & 0.31 & 0.09 & 0.45 & 0.05 & 0.09 & 0.01 \\
\hline
\end{tabular}

Table.3 Specific combining ability effects of hybrids for growth, earliness yield and quality parameters in ridge gourd

\begin{tabular}{|c|c|c|c|c|c|c|c|c|c|c|c|c|c|c|c|c|}
\hline $\begin{array}{l}\text { SI. } \\
\text { NO. }\end{array}$ & Crosses & $\begin{array}{c}\text { Number of } \\
\text { leaves on } \\
90 \text { DAS }\end{array}$ & $\begin{array}{l}\text { Number of } \\
\text { branches at } \\
90 \text { DAS }\end{array}$ & $\begin{array}{l}\text { Days } \\
\text { to first } \\
\text { female } \\
\text { flower }\end{array}$ & $\begin{array}{c}\text { Node to first } \\
\text { female } \\
\text { flower }\end{array}$ & $\begin{array}{c}\text { Days } \\
\text { to } \\
\text { first harvest }\end{array}$ & Sex ratio & $\begin{array}{c}\text { Number of } \\
\text { fruits per } \\
\text { vine }\end{array}$ & $\begin{array}{c}\text { Average } \\
\text { fruit weight }\end{array}$ & Fruit length & $\begin{array}{c}\text { Fruit } \\
\text { diameter }\end{array}$ & \begin{tabular}{|c|} 
Fruit \\
yield/vine
\end{tabular} & \begin{tabular}{|c} 
Estimated \\
fruit yield/ha
\end{tabular} & $\begin{array}{l}\text { Rind thick } \\
\text { ness }\end{array}$ & $\begin{array}{l}\text { Flesh } \\
\text { thick } \\
\text { ness }\end{array}$ & $\begin{array}{l}\text { Total } \\
\text { crude } \\
\text { fibre } \\
\text { content }\end{array}$ \\
\hline 1 & $L_{1 \times} T_{1}$ & -1.28 & $0.41 * *$ & -2.06 & -0.89 & $-14.44 * *$ & $0.66^{* * *}$ & $-1.36^{*}$ & -4.35 & $-2.21 *$ & 0.42 & $-0.36^{*}$ & $-2.71 * *$ & 0.08 & -0.16 & -0.02 \\
\hline 2 & $\mathbf{L}_{1 \times} \times T_{2}$ & 1.34 & 0.19 & 0.55 & -0.28 & -0.74 & 0.17 & -0.40 & -3.30 & -1.60 & 0.46 & -0.08 & -0.53 & $-0.24 * *$ & 0.27 & 0.03 \\
\hline 3 & $L_{1 \times} T_{3}$ & 0.12 & -0.09 & -1.04 & $1.14 *$ & $9.92 * *$ & -0.21 & 0.29 & 3.49 & $-2.25^{*}$ & $-1.28 * *$ & 0.11 & 0.77 & $0.27 * *$ & -0.09 & 0.01 \\
\hline 4 & $\mathbf{L}_{1 \times} \mathbf{T}_{4}$ & -0.18 & $-0.51 * *$ & $2.54^{*}$ & 0.03 & $5.25^{*}$ & $-0.62 *$ & $1.46^{*}$ & 4.16 & $6.07 * *$ & 0.39 & $0.33 *$ & $2.47 * *$ & -0.11 & -0.02 & -0.02 \\
\hline 5 & $\mathbf{L}_{2} \times \mathbf{T}_{1}$ & -1.70 & $-0.51 * *$ & -0.64 & -0.11 & $5.46^{*}$ & $0.62 *$ & 0.62 & -0.51 & $-4.06 *$ & $-1.17 *$ & 0.12 & 0.88 & -0.03 & 0.08 & -0.00 \\
\hline 7 & $\mathbf{L}_{2} \times \mathbf{T}_{3}$ & $2.50^{*}$ & 0.09 & -0.66 & 0.02 & -1.38 & 0.27 & $-1.63^{*}$ & 8.69 & $2.96 * *$ & 0.07 & -0.13 & -1.04 & -0.05 & 0.01 & -0.02 \\
\hline 8 & $\mathbf{L}_{2} \times \mathbf{T}_{4}$ & $-2.93 * *$ & $0.40 * *$ & 0.19 & 0.47 & 0.89 & -0.28 & -0.00 & -10.70 & -1.16 & 0.23 & -0.13 & -0.99 & 0.05 & -0.16 & 0.01 \\
\hline 9 & $\mathrm{~L}_{3 \times} \mathrm{T}_{1}$ & $2.12^{*}$ & 0.26 & 1.10 & -0.11 & -1.58 & $-0.70^{* *}$ & 1.06 & 5.36 & $3.94 * *$ & 0.35 & $0.36^{*}$ & $2.77 * *$ & -0.05 & -0.13 & 0.02 \\
\hline 10 & $\mathbf{L}_{3} \times \mathbf{T}_{2}$ & $-2.83^{*}$ & -0.22 & -1.31 & 0.20 & 2.12 & $1.43^{* *}$ & 0.16 & 9.30 & 0.44 & 0.00 & 0.17 & 1.08 & 0.14 & -0.19 & $-0.05^{*}$ \\
\hline 11 & $\mathbf{L}_{3} \times \mathbf{T}_{3}$ & -1.58 & -0.01 & 0.13 & 0.53 & -3.14 & -0.30 & 0.47 & $-14.97 *$ & -0.57 & 0.38 & -0.20 & $-1.42 *$ & $-0.38 * *$ & 0.02 & 0.01 \\
\hline 12 & $\mathbf{L}_{3} \times \mathbf{T}_{4}$ & $3.85^{* *}$ & -0.03 & 0.01 & -0.62 & 2.59 & -0.43 & $-1.69^{*}$ & 0.30 & $-3.81^{* *}$ & -0.73 & $-0.33^{*}$ & $-2.43 * *$ & $0.29 * *$ & $0.30^{*}$ & 0.01 \\
\hline 13 & $\mathbf{L}_{4} \times \mathbf{T}_{1}$ & $2.42 *$ & -0.16 & 1.52 & $1.11^{*}$ & $10.56 * *$ & $-0.59^{*}$ & -0.32 & -0.50 & $2.34 *$ & 0.40 & -0.12 & -0.95 & 0.00 & 0.21 & 0.00 \\
\hline 14 & $\mathbf{L}_{4} \times \mathbf{T}_{2}$ & -0.62 & 0.02 & -0.34 & 0.45 & 3.59 & $-0.99 * *$ & -0.78 & -8.53 & -1.10 & $-1.34 * *$ & -0.24 & $-1.69^{*}$ & 0.07 & -0.15 & 0.00 \\
\hline 16 & $\mathbf{L}_{4} \times \mathbf{T}_{4}$ & -0.75 & 0.14 & $-2.75^{*}$ & 0.13 & $-8.74 * *$ & $1.33 * *$ & 0.23 & 6.24 & -1.10 & 0.11 & 0.13 & 0.95 & $-0.23 *$ & -0.12 & -0.00 \\
\hline
\end{tabular}


Due to predominant role of non-additive gene action for yield and its components, it is difficult to bring together desirable genes by pedigree method. In this situation formation of central gene pool by bringing together the multiple parents having the good gca effects suggested by Jensen (1970) might prove to be useful.

The crosses having desired significant specific combining effects are presented in Table 3. Out of 16 crosses, two crosses exhibited positively significant and two crosses exhibited negatively significant sca effects for fruit yield per vine. Maximum and positively significant $s c a$ effects was observed in the cross $\mathrm{L}_{3} \mathrm{XT}_{1}(0.36)$ followed by $\mathrm{L}_{1} \mathrm{xT}_{4}$ (0.33).

The highest positive sca effects was exhibited (Table 3 ) by the cross $\mathrm{L}_{3} \mathrm{XT}_{4}$ (3.85) followed by for number of leaves per vine. Number of branches was maximum and significant sca effects were exhibited by $\mathrm{L}_{1} \mathrm{xT}_{1}(0.41)$ and $\mathrm{L}_{2} \mathrm{~T}_{4}$ (0.40). Days to first female flower appearance, in the cross $\mathrm{L}_{4} \mathrm{xT}_{4} \quad(-2.75)$ exhibited negative and significant sca effects. Among the crosses only cross $\mathrm{L}_{4} \times \mathrm{T}_{3}(-1.69)$ was exhibited negative and significant sca effects for node to first female flower appearance which is desirable. These results are in agreement with Prabhakar (2008). A comparison of the sca effects of the crosses and $g c a$ effects of the parents involved indicated that most of the cases $g c a$ effects were reflected in the sca effects of the cross combination.

The cross $\mathrm{L}_{1} \mathrm{xT}_{4}(-0.62)$ followed by $\mathrm{L}_{2} \mathrm{xT}_{2}(-$ 0.61) exhibited significant in desirable direction (negative) for sex ratio. For fruit length maximum and significant sca effects was observed in the cross $\mathrm{L}_{1} \mathrm{xT}_{4}$ (6.07) followed by $\mathrm{L}_{4} \mathrm{XT}_{1}$ (2.34). None of the crosses exhibited positive and significant sca effects for average fruit weight and fruit diameter.
Maximum and significant sca effects was observed in the cross $\mathrm{L}_{1} \mathrm{xT}_{3}(0.27)$ followed by $\mathrm{L}_{3} \mathrm{XT}_{4}(0.29)$ for rind thickness. Flesh in thickness the cross $\mathrm{L}_{3} \mathrm{XT}_{4} \quad(0.30)$ showed significant positive sca effect. These results are in agreement with Tyagi et al., (2010).

The crosses involving parents with good general combining ability effects can be exploited effectively by conventional breeding procedure like pedigree method. However the crosses one good combiner and other average or poor combiner could produce desirable transgressive segregators if additive genetic system was operative in good combining parents and epistatic effects also act in the same direction. The crosses exploited for hybrid vigour and hybrid derivative is $\mathrm{L}_{3} \times \mathrm{T}_{1}$ and $\mathrm{L}_{1} \mathrm{xT}_{4}$.

\section{References}

Ahmed I, Reddy P, Neeraja G (2006) Combining ability and heterosis for yield and yield components in ridge gourd (Luffa acutangula L.). J. Res. ANGRAU 34(1): 15-20.

Jensen HS, (1970) A diallel selective mating system for cereal breeding. Crop sci., 10: 629-635.

Kempthorne O, (1957) An introduction to genetic statistics. John Wiley and Sons, New York, pp. 408- 711.

Kempthorne, O. 1957. An Introduction to genetic statistics. John Wiley \& Sons Inc., New York.

Neeraja PB (2008) Combining ability and heterosis for fruit yield and yield components in ridge gourd (Luffa acutangula L.). J. Res. ANGRAU 36(4): 24-32.

Prabhakar, B.N. (2008).Combining ability and heterosis for fruit yield and yield components in ridge gourd (Luffa $\begin{array}{lll}\text { acutangula (Roxb.) } & \text { L.). }\end{array}$ J.Res.ANGRAU, 36(4):24-32. 
Purohit VL, Mehta DR, Dhaduk LK, Gajipara NN, (2007) Combining ability for fruit yield and its attributes in ridge gourd [Luffa acutangula L.]. Veg. Sci., 34(1): 84-85. 5.

Rao, B. N., P. V. Rao and B. M. M. Reddy. 2000. Correlation and path analysis in the segregating population of ridge gourd (Luffa acutangula (Roxb.) L.). Crop Res. 20(2): 338-342.
Shaha, S. R. and Kale, P. N., 2003b, Diallel analysis for combining ability in ridge gourd. J. Maharastra Agril. Univ., 28(3): 252-254.

Tyagi, S. V. S., P. Sharma, S. A. Siddiqui and R. C. Khandelwal. 2010. Combining Ability for Yield and Fruit Quality in Luffa acutangula Roxb. Int. J. Veg. Sci. 16: 267-277.

\section{How to cite this article:}

Nandhini, D., M. Ananthan, V. Krishnamoorthy and Anand, G. 2018. Combining Ability Analysis in Ridge Gourd [Luffa acutangula (L.) Roxb.]. Int.J.Curr.Microbiol.App.Sci. 7(05): 3120-3125. doi: https://doi.org/10.20546/ijcmas.2018.705.364 